\title{
1 In silico screening of potent bioactive compounds from honey bee products 2 against COVID-19 target enzymes
}

3

4 Moataz A. Shaldam ${ }^{1}$, Galal Yahya ${ }^{2,3}$, Nashwa H. Mohamed ${ }^{4}$, Mohamed M. Abdel-Daim ${ }^{5,6}$, 5 Yahya Al Naggar $5,6 *$

6

$7{ }^{1}$ Department of Pharmaceutical Chemistry, Faculty of Pharmacy, Kafr EL Sheikh University, 8 Kafr El Sheikh, 33516, Egypt.

$9{ }^{2}$ Microbiology and Immunology Department, Faculty of Pharmacy, Zagazig University 44519, 10 Al Sharqia, Egypt.

$11{ }^{3}$ Department of Molecular Genetics, Faculty of Biology, Technical University of Kaiserslautern, 12 Paul-Ehrlich Str. 24, Kaiserslautern 67663, Germany.

$13{ }^{4}$ Hospitals of Zagazig University, Al Sharqia, Egypt.

$14{ }^{5}$ Department of Zoology, College of Science, King Saud University, P.O. Box 2455, Riyadh

$15 \quad$ 11451, Saudi Arabia

$16{ }^{6}$ Pharmacology Department, Faculty of Veterinary Medicine, Suez Canal University, Ismailia

17 41522, Egypt

$18{ }^{7}$ Zoology Department, Faculty of Science, Tanta University31527, Tanta, Egypt.

$19{ }^{8}$ General Zoology, Institute for Biology, Martin Luther University Halle-Wittenberg, Hoher weg

20 8, 06120 Halle (Saale), Germany.

21

$22 *$ Correspondence:

23 Dr Y. Al Naggar, General Zoology, Institute for Biology, Martin Luther University Halle-

24 Wittenberg, Hoher Weg 8, 06120 Halle (Saale), Germany

25 E-mail: yehia.elnagar@science.tanta.edu.eg

26 Telephone: +49-345 5526511

27 FAX: +49-345 5527428 
From the early days of the COVID-19 pandemic, side by side to immense investigates to design

31 specific drugs or to develop a potential vaccine for the novel coronavirus. Myriads of FDA

32 approved drugs are massively repurposed for COVID-19 treatment based on molecular docking

33 of selected protein targets that play vital for the replication cycle of the virus. Honey bee

34 products are well known of their nutritional values and medicinal effects. Antimicrobial activity

35 of bee products and natural honey have been documented in several clinical studies and was

36 considered a good alternative for antiviral medications to treat some viral infections. Bee

37 products contain bioactive compounds in the form of a collection of phenolic acids, flavonoids

38 and terpenes of natural origin. We revealed by molecular docking the profound binding affinity

39 of 14 selected phenolics and terpenes present in honey and propolis (bees glue) against the main

40 protease $\left(\mathrm{M}^{\mathrm{pro}}\right)$ and RNA dependent RNA polymerase (RdRp) enzymes of the novel 2019-nCoV

41 coronavirus. Of these compounds, $p$-coumaric acid, ellagic acid, kaemferol and quercetin has the

42 strongest interaction with the 2019-nCoV target enzymes, and they may be considered as an

43 effective 2019-nCoV inhibitors.

44 Key words: COVID-19, Honey Bee products, Phenolic compounds, Molecular docking, Drug 45 repurposing, Natural products. 
Owing to increased global travel and rapid urbanization, viruses are responsible for a 54 variety of human pathologies. In December 2019, several cases of pneumonia of unknown cause were detected in Wuhan, province of Hubei in China. Most patients shared similar symptoms of 56 dry cough, fever, and fatigue, then they developed into dyspnea quickly, ending up with acute 57 respiratory distress syndrome (ARDS) (Chen et al. 2020, Chan et al. 2020, Zhu et al. 2020, 58 Huang et al. 2020, Zhou et al. 2020). By whole-genome sequencing of samples obtained from 59 lower respiratory tract of the patients, a new coronavirus was detected, further investigations revealed that the novel corona virus is different from severe acute respiratory syndrome (SARS)

61 and middle east respiratory syndrome (MERS) coronavirus (Zhu et al. 2020). On February 11, 62 2020, World Health Organization (WHO) named it coronavirus disease-19 (COVID-19) 63 officially, then declared it a pandemic on March 12, 2020 (World Health Organization 2020). whereas more than 400,000 cases died (2020b). As a direct effect of the outbreak of COVID-19,

67 more than 160 countries are fighting to combat the spread of COVID-19 and taking protective 68 measures to save their citizens from the pandemic, at the same time research institutes, drug 69 corporations, biotechnology institutes, research groups in different universities all over the world 70 are racing to develop effective drugs or potential vaccines for COVI-19. Internationally by June 71 2020, there are over 159 vaccine candidates (Sharpe et al. 2020, Thanh Le et al. 2020) and more 72 than 300 potential therapies for COVID-19 disease in various stages of preclinical or clinical 73 research (Pooladanda et al. 2020, Hachfi and Ben Lasfar 2020, 2020a, Mullard 2020). 
As a fast track to save time needed for safety and approval studies, researchers started to massively repurpose already FDA approved drugs for Covid19 treatment (Kandeel and AlNazawi 2020, Harrison 2020). Computational based techniques like molecular modeling and

77 virtual screening represent magic tools to understand the molecular aspects of protein ligand

78 interactions during rational drug design process (Murgueitio et al. 2012). Virtual screening has 79 been encountered in structure-based drug design against emerging and fatal diseases of viral 80 origin. (Sirois et al. 2004, Elhefnawi et al. 2012, Raj and Varadwaj 2016, Zhou et al. 2008, 81 Plewczynski et al. 2007).

82 Based on their crucial role in the life cycle of SARS CoV2, COVID -19 RNA-dependent 83 RNA polymerase (RdRp) (Gao et al. 2020) and the main protease (Mpro) (Jin et al. 2020) have 84 been extensively docked to design or distinguish effective drugs for COVID-19. Bioactive 85 compounds from natural origin are currently screened by molecular docking to in silico test their 86 affinity to molecular targets of COVID-19 taking the advantage that natural product are free 87 from toxic or side effects (Mani et al. 2020, Sayed et al. 2020, Gurung et al. 2020). Of the natural 88 products that recently acquired increasing prophylactic importance to combat viral infections in 89 general and COVID-19 in particular are honey bee products.

Honey bees are the "Golden insects" that produce honey and other vital honeybee products.

91 Their products have a long history in medicine. All cultures have traditions of folk medicine 92 which include the use of honey bee products, i.e. honey, bee pollen, propolis, royal jelly, 93 beeswax, and bee venom. It was found that these products display anti-inflammatory, anti94 bacterial, anti-fungal, anti-viral, antioxidant activities and neuroprotection (Pasupuleti et al. 95 2017, El-Seedi et al. 2020). Recently, honey has been proposed as a potential compatible 96 antiseptic prophylaxis to help protect against the COVID-19 based on biocidal effect of 
97 hydrogen peroxide that produced in most traditional honeys (Al Naggar et al. 2020, in press).

98 However, the potential bioactive compounds derived from honey and other bee products are not 99 identified yet and deserve more attention.

Therefore, the aim of the present study is to perform deep virtual screening via molecular

101 docking to test binding affinity of various selected bioactive compounds such as terpenes and

102 flavonoids of honey and propolis as inhibitors against COVID-19 essential enzymes: RNA103 dependent RNA polymerase and the main protease.

\section{Docking methodology}

The crystal structure of COVID -19 RNA-dependent RNA polymerase (RdRp) (PDB were retrieved from Protein Data Bank. This study was carried out on 14 compounds (Fig. 1) from honey and propolis into the receptor active site using AutoDock Vina (Trott and Olson 2010). Ligand structures were drawn into Marvin Sketch V19.12 (2020c) and the most energetically favored conformer was exported as (*.pdb) file format. AutoDockTools package (Morris et al. 2009) was used to assign Gasteiger atomic partial charges and all the rotatable

112 bonds in ligands were set to be flexible. For receptor preparation, all water molecules were removed, the co-crystalized ligand was removed, Gasteiger atomic partial charges were assigned

114 and all receptors and ligands were converted to the PDBQT format using AutoDockTools 115 package for docking process. In the AutoDock Vina configuration files, the parameter num 116 modes was set to 10 and exhaustiveness to 14 . The grid boxes of center $(x=118.23, y=103.32$ 117 and $\mathrm{z}=118.37)$ with size $(\mathrm{x}=17, \mathrm{y}=25, \mathrm{z}=17)$ for the RNA-dependent RNA polymerase and 118 center $(x=-10.71, y=12.41$ and $z=68.83)$ with size $(x=16, y=18, z=16)$ for the main protease 119 were used to define the active site. AutoDock Vina was executed. Pymol (2020d) was used for 
$1203 \mathrm{D}$ visualization and the 2D schematic presentation was generated using LigPlot+ V1.4.5

121 (Laskowski and Swindells 2011).

122 Results and discussion

Honey bee products contain minor amounts of flavonoids, phenols, phenolic acids, 124 carotenoids and terpenes (Fig. 1). These phenolic compounds and terpenes found to possess 125 variable medicinal effects including wound healing, antioxidant, antimicrobial, antiviral, anti126 inflammatory, cardioprotective, and neuroprotective activities (Biesalski et al. 2009; Küçük et al. 127 2007; El-Seedi et al. 2020). Recently many drugs that are designed and clinically implicated for 128 other medicinal aspects have been repurposed for COVID-19 treatment (Kandeel and Al-Nazawi 129 2020, Oliveira et al. 2020). Therefore, honey bee products represent a natural pharmacy that 130 harbor collection of remedies of broad medicinal effects and might be repurposed against 131 COVID-19. Bioinformatics is one of the most important and innovative approaches to design new 133 drugs (Li et al., 2020). Due to the high cost of clinical and laboratory trials, the time consuming 134 and the possibility of error, different bioinformatics techniques are nowadays used in the design 135 of new drugs (Shaghaghi, 2020). In the current study, computational docking was implemented 136 to predict the binding mode of 14 compounds from honey and propolis with two different targets 137 from COVID-19; RNA-dependent RNA polymerase (RdRp) (PDB code: 6M71) and the main 138 protease $\left(\mathrm{M}^{\mathrm{pro}}\right.$ ) (PDB code: 6LU7). We revealed that the bioactive compounds; ellagic acid, 139 hesperetin, and kaempferol are the most promising compounds on COVID-19 RdRp while 140 artepillin C, ellagic acid, hesperetin, kaempferol and quercetin were the most active on the main 141 protease (Mpro). The binding scores for each compound into the two targets are shown in Table 142 1. The binding mode for ellagic acid to COVID-19 RdRb site was attributed to H-bond 
143 interaction with Gly808, pro809, His816, Thr817 and Tyr 831, while amino acid residues

144 Trp617, Asp760 and Asp761 are positioned at distance of H-bond with hesperetin, and also

145 kaempferol interacts with Glu811 and Asp761 by H-bond. Furthermore, the aromatic ring system

146 of ellagic acid, hesperetin and kaempferol make $\pi$-ion hydrophobic interaction with Lys798 (Fig.

147 2). We spot the light on the high affinity bioactive compounds like phenolic and flavonoids of

148 honey as potent inhibitors of viral replication.

From the docking of all identified compounds into the active site of SARS-CoV-2 main 150 protease $\left(\mathrm{M}^{\mathrm{pro}}\right)$ in the current study, artepillin $\mathrm{C}$ showed H-bond interaction with Cys145, 151 Arg188, Thr190 and Gln192, while amino acid residues His41, Gly143 and Arg188 are 152 positioned at distance of $\mathrm{H}$-bond with ellagic acid (Fig. 3). In addition, hesperetin interacts 153 with Gly143 by H-bond while amino acid residues Tyr54, Leu141, Ser144, Asp 187 and Gln189 154 are positioned at distance of H-bond with kaempferol, and also quercetin makes H-bond with 155 Tyr54, Leu141, Ser144, His163, and Gln189. Furthermore, the aromatic ring system of artepillin $156 \mathrm{C}$, ellagic acid, hesperetin, kaempferol and quercetin make $\pi$-ion hydrophobic interaction with 157 either Met165 or Glu166 (Fig. 4). Taken together we propose phenolic acids and flavonoids from 158 honey bee products as potential inhibitor of the main protease of SARS-CoV-2 (COVID-19).

159 In the same context, our promising candidates like $p$-coumaric acid, ellagic acid, 160 kaemferol and quercetin were previously found to have potential antiviral activity against the 161 common cold human rhinovirus which is RNA virus like SARS-CoV2. Surprisingly the 162 mentioned bioactive compounds were suggested in the same study to block or reduce the viral 163 entry into the cells to protect the cells from the virus cytopathic effects and subside virus 164 replication (Kwon et al. 2019), supporting our virtual screening. Moreover, quercetin and its 165 derivatives were previously confirmed to inhibit the SARS-CoV proteases (Nguyen et al. 2012). 
166 and other coronaviruses including SARS-CoV proteases (3CLpro and PLpro) as well as the

167 Middle Eastern Respiratory Syndrome coronavirus (MERS-CoV) 3CLpro protease. Quercetin

168 was also able to inhibit both enzymes in vitro in micromolar doses (Park et al. 2017).

169 Conclusions

170 Theoretical studies through molecular docking of collection of bioactive compounds of

171 honey bee products against selected targets of COVID-19 including Mpro and RdRb enzymes of

172 the 2019-nCoV virus have distinguished promising bioactive compounds of natural origin that

173 exhibited profound binding to the respective COVID- 19 targets. Among the investigated

174 bioactive compounds derived from honey and propolis, $p$-coumaric acid, ellagic acid, kaemferol

175 and quercetin are the most promising compounds on 2019-nCoV active sites (RdRb and Mpro)

176 These potent bioactive compounds were also found to have potential antiviral activity against the

177 common cold human rhinovirus which is RNA virus like SARS-CoV2. Taken all together and

178 based on our theoretical studies supported by previous in vitro confirmatory studies, we

179 recommend further in vivo investigations to assess the predicted affinity of the selected

180 compounds against the novel coronavirus (COVID-19) target enzymes.

181 Acknowledgments

182 We wish to confirm that there are no known conflicts of interest associated with this 183 publication, and there has been no significant financial support for this work that could have 184 influenced its outcome. YA \& GY are grateful to Alexander von Humboldt (AvH) foundation for 185 post-doc fellowships. 


\section{References}

Al Naggar, Yahya; Ansari, Mohamed; Giesy, John; Yahya, Galal (2020, in press). Repurposing Honey for Antiseptic Prophylaxis against Novel Coronavirus COVID-19. In Natural Product Research.

Biopharma products in development for COVID-19 (2020a). https://www.bioworld.com/COVID19products. Accessed 11 Jun 2020

Chan JF-W, Yuan S, Kok K-H, To KK-W, Chu H, Yang J, Xing F, Liu J, Yip CC-Y, Poon RWS, Tsoi H-W, Lo SK-F, Chan K-H, Poon VK-M, Chan W-M, Ip JD, Cai J-P, Cheng VC-C, Chen H, Hui CK-M, Yuen K-Y (2020) A familial cluster of pneumonia associated with the 2019 novel coronavirus indicating person-to-person transmission: a study of a family cluster. Lancet (London, England) 395(10223):514-523. doi: 10.1016/S0140-6736(20)30154-9

Chen N, Zhou M, Dong X, Qu J, Gong F, Han Y, Qiu Y, Wang J, Liu Y, Wei Y, Xia J'a, Yu T, Zhang X, Zhang L (2020) Epidemiological and clinical characteristics of 99 cases of 2019 novel coronavirus pneumonia in Wuhan, China: a descriptive study. Lancet (London, England) 395(10223):507-513. doi: 10.1016/S0140-6736(20)30211-7

Coronavirus Update (Live): COVID-19 Virus Pandemic - Worldometer (2020b). https://www.worldometers.info/coronavirus/. Accessed 13 Jun 2020

Elhefnawi M, ElGamacy M, Fares M (2012) Multiple virtual screening approaches for finding new hepatitis C virus RNA-dependent RNA polymerase inhibitors: structure-based screens and molecular dynamics for the pursue of new poly pharmacological inhibitors. BMC bioinformatics 13 Suppl 17:S5. doi: 10.1186/1471-2105-13-S17-S5

El-Seedi HR, Khalifa SAM, El-Wahed AA, Gao R, Guo Z, Tahir HE, Zhao C, Du M, Farag MA, Musharraf SG, Abbas G (2020) Honeybee products: An updated review of neurological actions. Trends in Food Science \& Technology 101:17-27. doi: 10.1016/j.tifs.2020.04.026

Gao Y, Yan L, Huang Y, Liu F, Zhao Y, Cao L, Wang T, Sun Q, Ming Z, Zhang L, Ge J, Zheng L, Zhang Y, Wang H, Zhu Y, Zhu C, Hu T, Hua T, Zhang B, Yang X, Li J, Yang H, Liu Z, Xu W, Guddat LW, Wang Q, Lou Z, Rao Z (2020) Structure of the RNA-dependent RNA polymerase from COVID-19 virus. Science (New York, N.Y.) 368(6492):779-782. doi: 10.1126/science.abb7498

Gurung AB, Ali MA, Lee J, Farah MA, Al-Anazi KM (2020) Unravelling lead antiviral phytochemicals for the inhibition of SARS-CoV-2 Mpro enzyme through in silico approach. Life sciences 255:117831. doi: 10.1016/j.1fs.2020.117831

Hachfi W, Ben Lasfar N (2020) COVID-19: Main therapeutic options. La Tunisie medicale 98(4):299-303

Harrison C (2020) Coronavirus puts drug repurposing on the fast track. Nature biotechnology 38(4):379-381. doi: 10.1038/d41587-020-00003-1

Huang C, Wang Y, Li X, Ren L, Zhao J, Hu Y, Zhang L, Fan G, Xu J, Gu X, Cheng Z, Yu T, Xia J, Wei Y, Wu W, Xie X, Yin W, Li H, Liu M, Xiao Y, Gao H, Guo L, Xie J, Wang G, Jiang R, Gao Z, Jin Q, Wang J, Cao B (2020) Clinical features of patients infected with 2019 
novel coronavirus in Wuhan, China. The Lancet 395(10223):497-506. doi: 10.1016/S01406736(20)30183-5

Jin Z, Du X, Xu Y, Deng Y, Liu M, Zhao Y, Zhang B, Li X, Zhang L, Peng C, Duan Y, Yu J, Wang L, Yang K, Liu F, Jiang R, Yang X, You T, Liu X, Yang X, Bai F, Liu H, Liu X, Guddat LW, Xu W, Xiao G, Qin C, Shi Z, Jiang H, Rao Z, Yang H (2020) Structure of Mpro from SARS-CoV-2 and discovery of its inhibitors. Nature. doi: 10.1038/s41586-020-2223-y

Kandeel M, Al-Nazawi M (2020) Virtual screening and repurposing of FDA approved drugs against COVID-19 main protease. Life sciences 251:117627. doi: 10.1016/j.lfs.2020.117627

Kwon MJ, Shin HM, Perumalsamy H, Wang X, Ahn Y-J (2019) Antiviral effects and possible mechanisms of action of constituents from Brazilian propolis and related compounds. Journal of Apicultural Research:1-13. doi: 10.1080/00218839.2019.1695715

Laskowski RA, Swindells MB (2011) LigPlot+: multiple ligand-protein interaction diagrams for drug discovery. Journal of chemical information and modeling 51(10):2778-2786. doi: $10.1021 / \mathrm{ci} 200227 \mathrm{u}$

Mani JS, Johnson JB, Steel JC, Broszczak DA, Neilsen PM, Walsh KB, Naiker M (2020) Natural product-derived phytochemicals as potential agents against coronaviruses: A review. Virus research 284:197989. doi: 10.1016/j.virusres.2020.197989

Marvin | ChemAxon. version 19.12, by ChemAxon (2020c). https://chemaxon.com/products/marvin. Accessed 11 Jun 2020

Morris GM, Huey R, Lindstrom W, Sanner MF, Belew RK, Goodsell DS, Olson AJ (2009) AutoDock4 and AutoDockTools4: Automated docking with selective receptor flexibility. Journal of computational chemistry 30(16):2785-2791. doi: 10.1002/jcc.21256

Mullard A (2020) Flooded by the torrent: the COVID-19 drug pipeline. Lancet (London, England) 395(10232):1245-1246. doi: 10.1016/S0140-6736(20)30894-1

Murgueitio MS, Bermudez M, Mortier J, Wolber G (2012) In silico virtual screening approaches for anti-viral drug discovery. Drug discovery today. Technologies 9(3):e219-25. doi: 10.1016/j.ddtec.2012.07.009

Nguyen TTH, Woo H-J, Kang H-K, van Nguyen D, Kim Y-M, Kim D-W, Ahn S-A, Xia Y, Kim D (2012) Flavonoid-mediated inhibition of SARS coronavirus 3C-like protease expressed in Pichia pastoris. Biotechnology letters 34(5):831-838. doi: 10.1007/s10529-011-0845-8

Oliveira OV de, Rocha GB, Paluch AS, Costa LT (2020) Repurposing approved drugs as inhibitors of SARS-CoV-2 S-protein from molecular modeling and virtual screening. Journal of biomolecular structure \& dynamics:1-10. doi: 10.1080/07391102.2020.1772885

Park J-Y, Yuk HJ, Ryu HW, Lim SH, Kim KS, Park KH, Ryu YB, Lee WS (2017) Evaluation of polyphenols from Broussonetia papyrifera as coronavirus protease inhibitors. Journal of enzyme inhibition and medicinal chemistry 32(1):504-515. doi: 10.1080/14756366.2016.1265519

Pasupuleti VR, Sammugam L, Ramesh N, Gan SH (2017) Honey, Propolis, and Royal Jelly: A Comprehensive Review of Their Biological Actions and Health Benefits. Oxidative medicine and cellular longevity 2017:1259510. doi: 10.1155/2017/1259510 
Plewczynski D, Hoffmann M, Grotthuss M von, Ginalski K, Rychewski L (2007) In silico prediction of SARS protease inhibitors by virtual high throughput screening. Chemical biology \& drug design 69(4):269-279. doi: 10.1111/j.1747-0285.2007.00475.x

Pooladanda V, Thatikonda S, Godugu C (2020) The current understanding and potential therapeutic options to combat COVID-19. Life sciences 254:117765. doi: 10.1016/j.lfs.2020.117765

PyMOL Molecular Visualization System. Version 2.0, by Schrödinger (2020d). https://pymol.org/2/. Accessed 11 Jun 2020

Raj U, Varadwaj PK (2016) Flavonoids as Multi-target Inhibitors for Proteins Associated with Ebola Virus: In Silico Discovery Using Virtual Screening and Molecular Docking Studies. Interdisciplinary sciences, computational life sciences 8(2):132-141. doi: 10.1007/s12539015-0109-8

Sayed AM, Khattab AR, AboulMagd AM, Hassan HM, Rateb ME, Zaid H, Abdelmohsen UR (2020) Nature as a treasure trove of potential anti-SARS-CoV drug leads: a structural/mechanistic rationale. RSC Adv. 10(34):19790-19802. doi: 10.1039/D0RA04199H

Sharpe HR, Gilbride C, Allen E, Belij-Rammerstorfer S, Bissett C, Ewer K, Lambe T (2020) The early landscape of COVID-19 vaccine development in the UK and rest of the world. Immunology. doi: 10.1111/imm.13222

Sirois S, Wei D-Q, Du Q, Chou K-C (2004) Virtual screening for SARS-CoV protease based on KZ7088 pharmacophore points. Journal of chemical information and computer sciences 44(3):1111-1122. doi: 10.1021/ci034270n

Thanh Le T, Andreadakis Z, Kumar A, Gómez Román R, Tollefsen S, Saville M, Mayhew S (2020) The COVID-19 vaccine development landscape. Nature reviews. Drug discovery 19(5):305-306. doi: 10.1038/d41573-020-00073-5

Trott O, Olson AJ (2010) AutoDock Vina: improving the speed and accuracy of docking with a new scoring function, efficient optimization, and multithreading. Journal of computational chemistry 31(2):455-461. doi: 10.1002/jcc.21334

World Health Organization (2020) Novel Coronavirus - China. https://www.who.int/csr/don/12january-2020-novel-coronavirus-china/en/. Accessed 11 Jun 2020

Zhou P, Yang X-L, Wang X-G, Hu B, Zhang L, Zhang W, Si H-R, Zhu Y, Li B, Huang C-L, Chen H-D, Chen J, Luo Y, Guo H, Jiang R-D, Liu M-Q, Chen Y, Shen X-R, Wang X, Zheng X-S, Zhao K, Chen Q-J, Deng F, Liu L-L, Yan B, Zhan F-X, Wang Y-Y, Xiao G-F, Shi Z-L (2020) A pneumonia outbreak associated with a new coronavirus of probable bat origin. Nature 579(7798):270-273. doi: 10.1038/s41586-020-2012-7

Zhou Z, Khaliq M, Suk J-E, Patkar C, Li L, Kuhn RJ, Post CB (2008) Antiviral compounds discovered by virtual screening of small-molecule libraries against dengue virus $\mathrm{E}$ protein. ACS chemical biology 3(12):765-775. doi: 10.1021/cb800176t

Zhu N, Zhang D, Wang W, Li X, Yang B, Song J, Zhao X, Huang B, Shi W, Lu R, Niu P, Zhan F, Ma X, Wang D, Xu W, Wu G, Gao GF, Tan W (2020) A Novel Coronavirus from Patients 
304 with Pneumonia in China, 2019. The New England journal of medicine 382(8):727-733. doi:

305 10.1056/NEJMoa2001017

306

307 
309

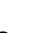

Figure 1. Chemical structure of important bioactive compounds in honey, propolis, and royal jelly.

Figure 2. The docking complex of (a) Ellagic acid, (b) Hesperetin and (c) Kaempferol (green) with the X-ray structure of 6M71; SARS-CoV-2 RNA-dependent RNA polymerase (left, Tint) that showed hydrogen bond (blue) interaction and 2D schematic diagram of the interaction (right).

Figure 3. The docking complex of (a) Artepillin $\mathbf{C}$ and (b) Ellagic acid (green) with the X-ray structure of 6LU7; SARS-CoV-2 main protease $\left(\mathrm{M}^{\mathrm{pro}}\right.$ ) (left, Tint) that showed hydrogen bond (blue) interaction and 2D schematic diagram of the interaction (right).

Figure 4. The docking complex of (a) Hesperetin (b) Kaempferol and (c) Quercetin (green) with the X-ray structure of 6LU7; SARS-CoV-2 main protease (M ${ }^{\text {pro }}$ ) (left, Tint) that showed hydrogen bond (blue) interaction and 2D schematic diagram of the interaction (right).

3

4

5

7

8

9

0

31

2

34

35

36

37


<smiles>CC(C)=CCc1cccc2c1OC(C)(C)C=C2</smiles>

2,2-Dimethyl-8-prenylchromene<smiles>CC1=C(CO)C2=C3CCC4C(C)(C(=O)O)CCC[C@]4(C)C3CCC2=C1CO</smiles>

Isocupressic acid<smiles>COc1cc(C(=O)O)cc(OC)c1O</smiles>

Syringic acid<smiles>COC1=CCC(=C2CC(=O)c3c(O)cc(O)cc3O2)C=C1O</smiles>

Hesperetin<smiles>CC(C)=CCc1cc(/C=C/C(=O)O)cc(CC=C(C)C)c1O</smiles>

4-Hydroxy-3,5-diprenyl cin
(Artepillin C)<smiles>CC1=CCC[C@H]2[C@@H]1CC[C@H](C(=O)O)[C@H]2CC/C(C)=C/CO</smiles>

13C-symphyoreticulic acid

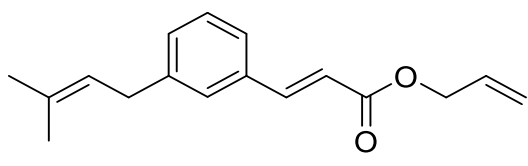

3-Prenyl cinnamic acid allyl ester<smiles>O=c1oc2c(O)c(O)cc3c(=O)oc4c(O)c(O)cc1c4c23</smiles>

Ellagic acid<smiles>O=C(/C=C/c1ccc(O)c(O)c1)OCCc1ccccc1</smiles>

Caffeic acid phenethyl ester<smiles>O=C(O)/C=C/c1ccc(O)cc1</smiles>

p-Coumaric acid<smiles>O=C1CC(c2ccc(O)cc2)Oc2cc(O)cc(O)c21</smiles><smiles>[R]c1cc(-c2oc3cc(O)cc(O)c3c(=O)c2[R])cc([R])c1O</smiles>

Naringenin 
(a)

347

348

349

350

351

352

353

354

355

356

357

358

359

360

361

362

363

364

365

366

367

368

369

370

371

372

373

(b)

(c)
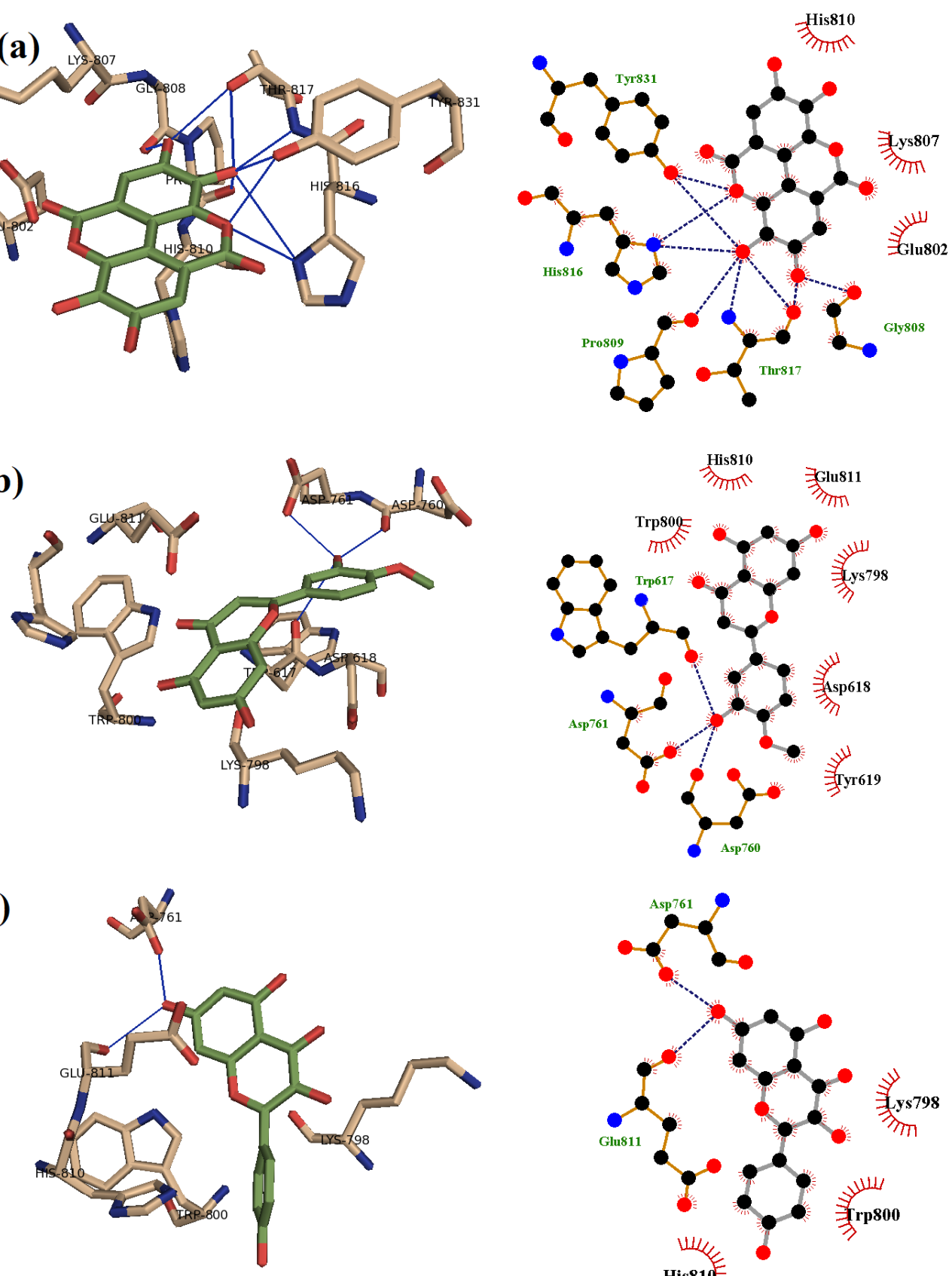
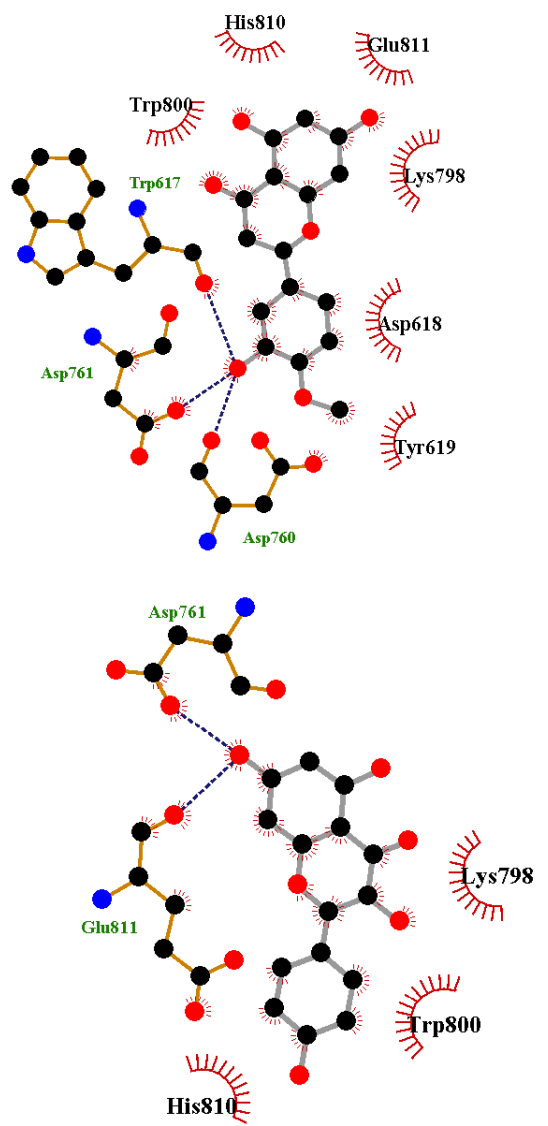
$374 \quad$ Fig.3

375

376
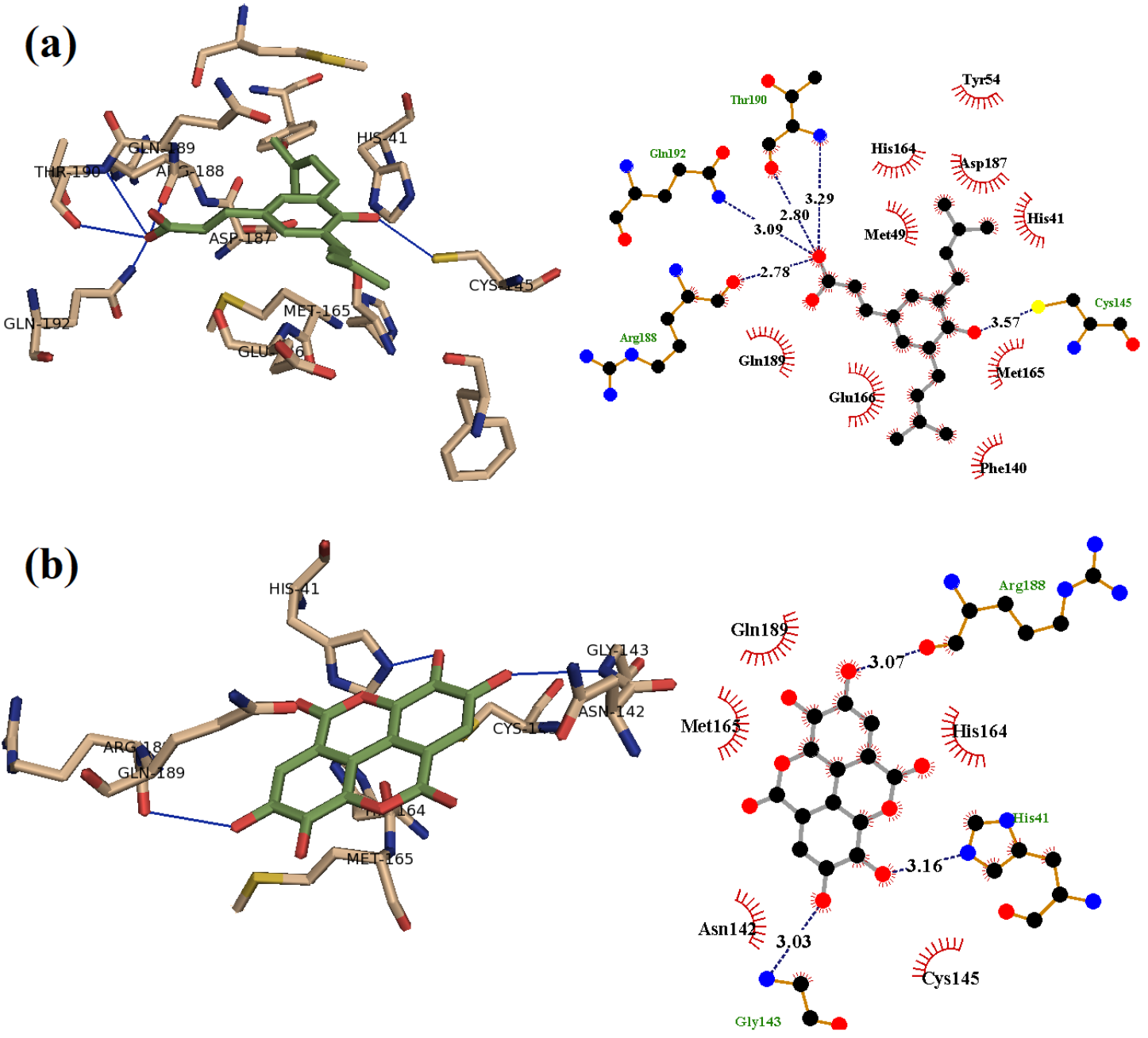
(a)

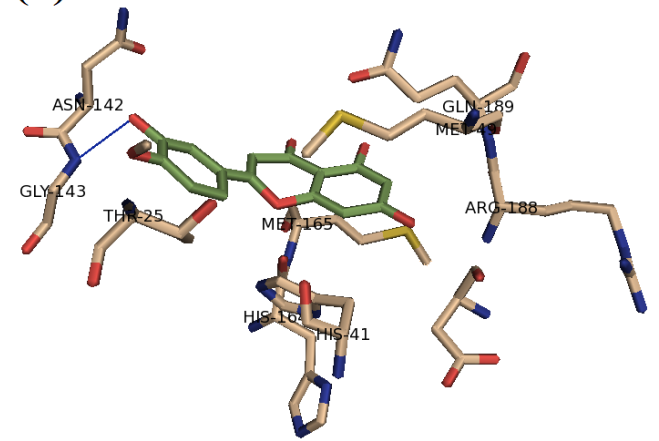

387

388

389

390

391

392

393

401

402
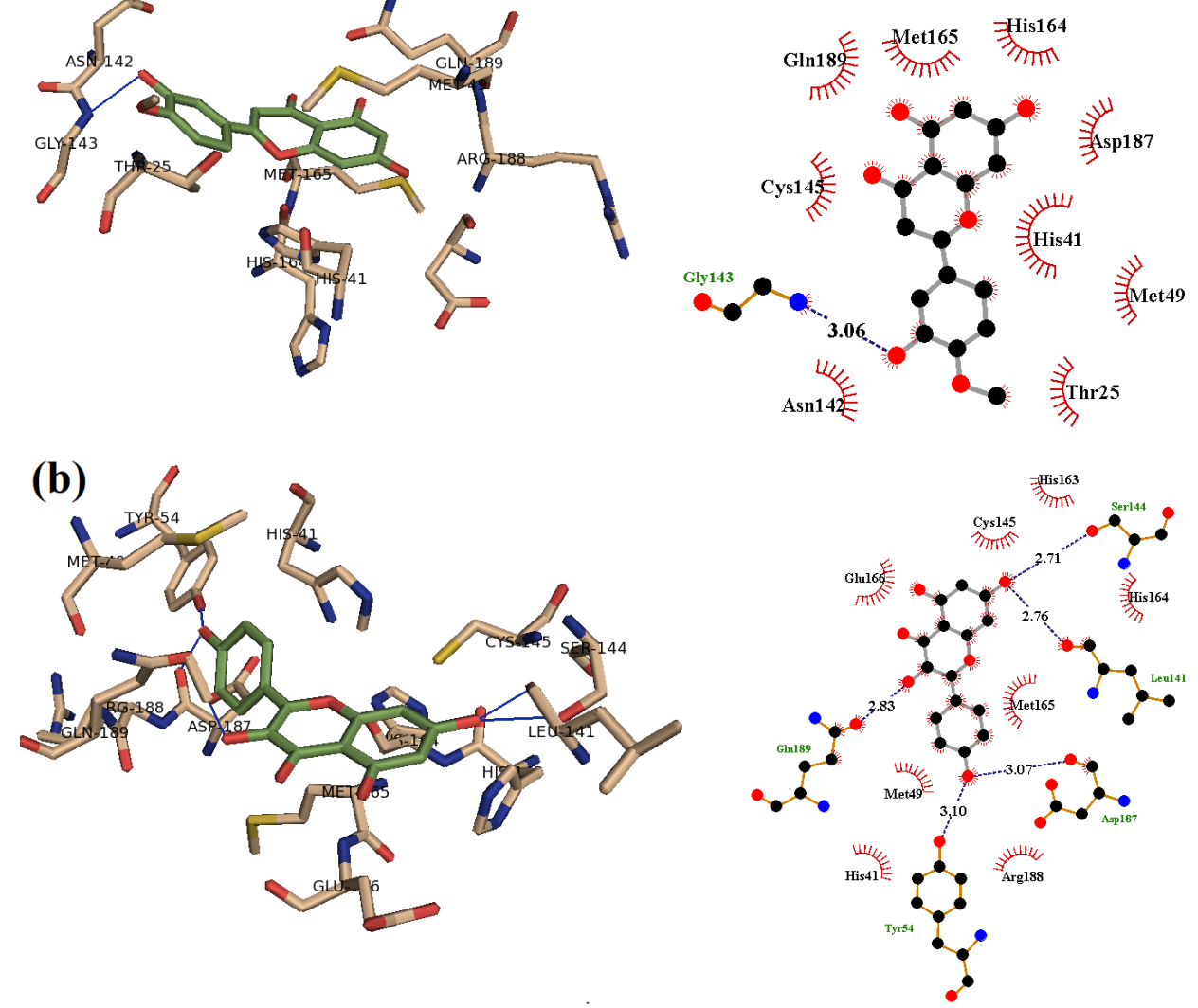

403

404

405

406
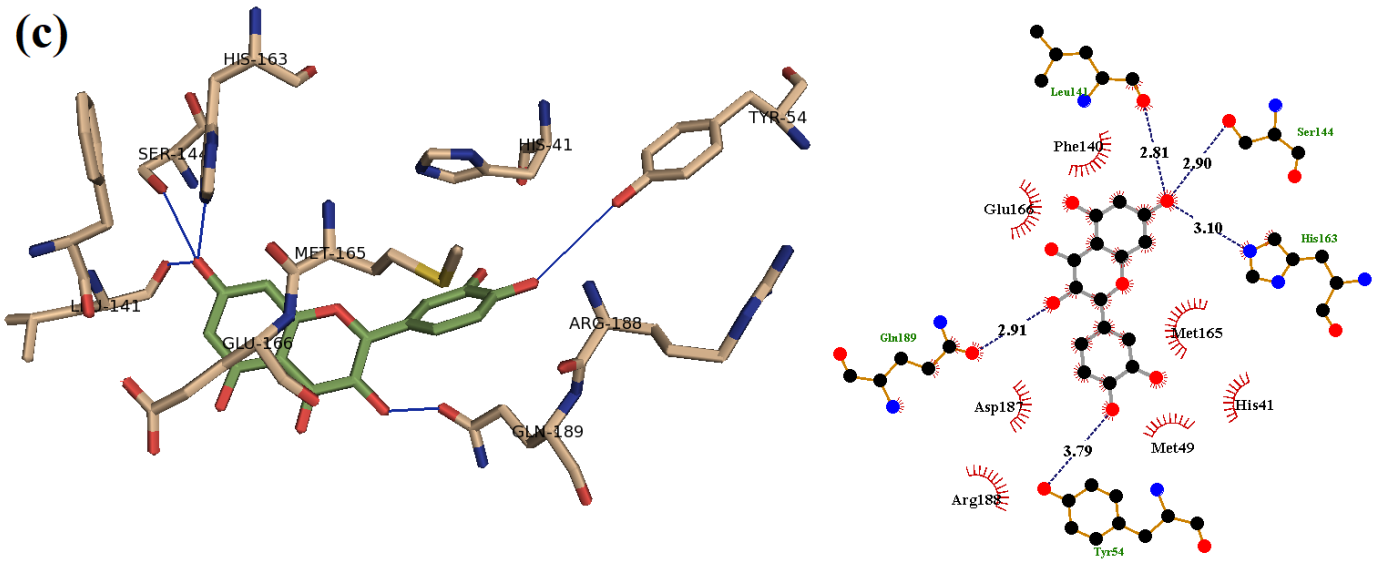
407 Table 1. The binding scores for each compound into the two target enzymes of SARS-CoV-

4082 RNA-dependent RNA polymerase $(\mathrm{RdRp})$ and the main protease $\left(\mathrm{M}^{\mathrm{pro}}\right)$

409 